\title{
THE TWO TASMANIAN SPECIES OF CALOROPHUS (RESTIONACEAE)
}

\author{
by L.A.S. Johnson and B.G. Briggs \\ (with two text-figures)
}

Calorophus ater L. Johnson \& B. Briggs sp. nov. from the sedgelands of southwestern and western Tasmania is described. Description and synonymy of $C$. elongatus are also provided.

Key Words: Restionaceae, Tasmania.

In BANKS, M.R. et al. (Eds), 1991 (31:iii): ASPECTS OF TASMANIAN BOTANY - A TRIBUTE TO WINIFRED CURTIS. Roy. Soc. Tasm. Hobart: 47-51. https://doi.org/10.26749/rstpp.124.2.47

\section{INTRODUCTION}

Ten species of Restionaceae were recognised in the Tasmanian flora until recently when Dr Winifred Curtis drew our attention to the distinctiveness of two further taxa. One has since been named as Winifredia sola L. Johnson \& B. Briggs (1985), a monotypic genus of the southwestern sedgelands. The other is the original Restio monocephalus R.Br., although that name has been widely misapplied to $R$. hookeri $\mathrm{D}$. Morris (1991), described in this volume. A further Tasmanian species of Calorophus has been recognised, initially through field studies by Dr Jean Jarman, but it is now apparent that a few specimens of this taxon have existed in herbaria since last century.

Calorophus had been considered a monotypic Tasmanian endemic genus (e.g. Johnson \& Briggs 1983) since Johnson \& Cutler (1974) erected Empodisma, consisting of E. minus (Hook. f.) L. Johnson \& Cutler and E. gracillimum (F. Muell.) L. Johnson \& Cutler. However, C. elongatus has since been found to occur in the Western Otways of southern Victoria (Harris 1984).

\section{KEY TO THE SPECIES}

1. Leaf sheaths green on young growth, often becoming brown with age, smooth or striate or sometimes slightly rough with minute black dots, the midrib commonly not depressed, the lamina up to $10 \mathrm{~mm}$ long; the fruit $2.3-3.5 \mathrm{~mm}$ long, dark brown, with fine pale striations.......C. elongatus

1. Leaf sheaths glossy and dark-red to dull black, minutely tuberculate, with a depressed midrib, the lamina $0.5-3 \mathrm{~mm}$ long; the fruit $3-4 \mathrm{~mm}$ long, dark red-brown or blackish brown, smooth or slightly furrowed when mature............. ater
Calorophus ater L. Johnson \& B. Briggs, sp. nov. (fig. 1, A-F)

A Calorophus elongata characteribus sequentibus distinguitur: vaginae foliorum tuberculatiores fuscioresque saepe atri, saepissime linea media depressa; laminae breviores ( $0.5 \mathrm{ad} 3 \mathrm{~mm}$ longae); nux laevior major ( 3 ad $4 \mathrm{~mm}$ longa) fusciorque.

\section{Typus}

Tasmania: Elliot Range, National Grid Ref. CN945964, 840 m a.s.l., J. Jarman 우, 13.i.1985. Holotypus: NSW 222690. Isotypi: $\mathrm{HO}, \mathrm{K}$.

\section{Description}

Dioecious. Forming dense tangled masses arising from a tufted base. Culms numerous, erect, much-branched, often stout and up to $2 \mathrm{~mm}$ diameter towards the base, often rooting at the lower nodes; slender, 0.3-1 mm diameter, wiry and flexuose above, c. 0.1-1 m long and reported to $3 \mathrm{~m}$ long, terete to slightly compressed or sometimes furrowed, \pm smooth to subscabrous, green, glabrous. Sheaths and floral bracts glossy and dark red to dull black, scarious, rigid, persistent, usually closely appressed to the culm or open when subtending a branching node; basal sheaths $10-30 \mathrm{~mm}$ long, smooth to minutely tuberculate, tuuncate, lamina short or absent; cauline sheaths 5-15 mm long, minutely tuberculate, usually with a conspicuously depressed midrib, obtuse to truncate with a short reflexed, subulate, often caducous lamina c. $0.5-3.0 \mathrm{~mm}$ long. Male spikelets single or in pairs in the axils, and when two in each axil then usually one shortly pedicellate and the other \pm sessile; the spikelets $3.0-3.5 \mathrm{~mm}$ long, cylindrical to narrowly-ovoid, with two glumes subtending a solitary flower, the glumes ovate-lanceolate, 1-2 mm long, acute and sometimes with a short awn, pale brown, membranous. Female spikelets solitary and terminal on branchlets up to $45 \mathrm{~mm}$ long; the spikelets $46 \mathrm{~mm}$ long, with two glumes subtending a solitary flower, the 

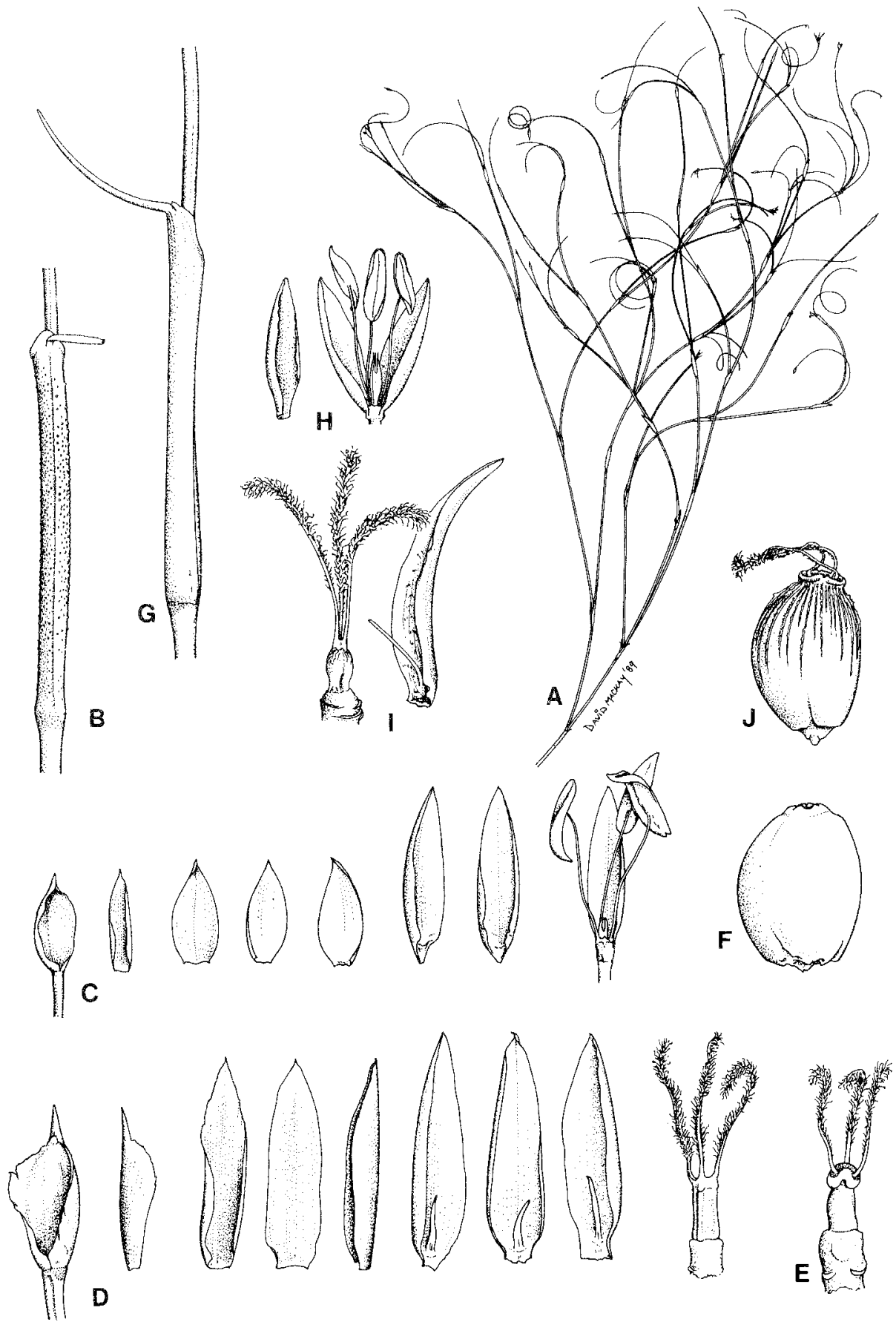

FIG. I A-F-Calorophus ater. (A) habit, $\times 0.4,(B)$ leaf sheath, $\times 4,(C)$ dissected $0^{\top}$ spikelet (one inner tepal with the stamens and pistillode), $\times 8,(D)$ dissected $O$ spikelet (with staminodes attached to inner tepals), $\times 8,(E)$ ovary, $\times 8,(F)$ fruit, $\times 8$. (A - Jarman, Mt Sprent; B-C - Jarman, Olga Valley; $D$ - Buchanan 6089; E-Jarman, Conder R.; F-Holotype.)

$G^{-} J$-Calorophus elongatus. $(G)$ leaf sheath, $\times 4,($ H) dissected flower (outer tepals not shown), $\times 8,(I)$ ovary and inner tepal with staminode, $\times 8,(J)$ fruit, $\times 8 .(G \& I-N S W 89708 ; H-N S W 91557 ; J-$ Harris 6.$)$ 
glumes ovate-lanceolate, $1.7-3.0 \mathrm{~mm}$ long, with a mucro $0.2-0.7 \mathrm{~mm}$ long, rigid with membranous margins, dark red-brown. Male flowers: tepals 6, lanceolate, acute, firm, pale brown, smooth, glabrous; 3 outer tepals $1.5-$ $2.2 \mathrm{~mm}$ long; 3 inner tepals $2-3 \mathrm{~mm}$ long; filaments 2.0-2.5 mm long; anthers 1.7-2.0 mm long; pistillode present, c. $0.4 \mathrm{~mm}$ long. Female flowers: tepals 6, similar to males but outer tepals $3.3-3.6 \mathrm{~mm}$ long, inner tepals 3.8-4.6 mm long; staminodes 3 , c. $1 \mathrm{~mm}$ long; ovary narrowly-ovoid; styles 3 -branched, wholly stigmatic, c. $2.5 \mathrm{~mm}$ long. $N u t$ hard, ellipsoid, 3-4 mm long, dark brown to dark red-brown, smooth or with irregular longitudinal furrows. Seed $2.0-2.5 \mathrm{~mm}$ long, pale, ellipsoid (fig. 1).

The specific epithet is from the Latin ater meaning black (especially dull black), referring to the colour of the sheaths.

Culms of Calorophus ater show the anatomical features of the genus as described by Johnson \& Cutler (1974) and no differences from C. elongatus in gross anatomy were distinguished.

\section{Distribution}

Western and southwestern Tasmania, south of $42^{\circ} \mathrm{S}$ lat., growing among and over shrubs and sedges, in sedgeland and heath in regions of peaty or sandy soils of low fertility from low altitudes to I100 $\mathrm{m}$ a.s.I. (fig. 2).

\section{Selected Specimens}

Tasmania: West Coast (regions as Orchard 1988) G. \& C. Davis Ot, Lake Margaret, 12.i.1937 (NSW); D. \& A. Ratkowsky 1477, Mt Jukes Rd, 9.iii.1974 (NSW); P. Collier 217a, Mt Darwin, 25.xii. 1984 (HO); N. Gibson $ᄋ$, east slopes of Prince of Wales Range, 16.ii.1986 (HO). South West - J. Jarman \&, Mt Lee, 3.iii.1978 (NSW); J. Jarman o, Conder R., 20.iii.1985 (NSW); J. Jarman , Olga Valley, west of Olga R., 27.i.1977 (NSW); A. Orchard 5422 Q, below Serpentine Dam, 6.viii.1981 (HO, NSW); J. Jarman $q$, slopes of Mt Sprent, 12.iii.1984 (NSW); A. Buchanan 6089 \&, south slope of Mt Osmund, 3.iii.1985 (HO, NSW); J. Jarman Oै, Red Knoll, 18.xii.1984 (NSW); M. Brown 1372 Q, summit area of Mt Propsting, 10.iv. 1986 (HO); J. Jarman, Greystone Bluff, 28.ii.1979 (NSW); J. Jarman Oే, Melaleuca, 9.iii.1985 (NSW); Stuart $ᄋ$, Mt La Perouse (MEL 15109); C. St[uart] $\rho$, near Mt La Perouse, 20.iv.[18]56 (MEL 14966).

The status of the name Hypolaena longissima Benth. is dealt with below in the synonymy of Calorophus elongatus where it is lectotypified. Bentham described the sheaths as often dark-coloured but this is consistent with $C$. elongatus. There is no evidence that the Stuart specimens in MEL (cited above) formed part of Bentham's concept of Hypolaena longissima.

\section{Calorophus elongatus}

(fig. 1, G-J)

Calorophus elongatus Labillardière 1806, Now. Holl. Pl. Spec. II: 78, t.228.

\section{Syntypes}

In capite Van-Diemen [Tasmania], Labillardière,, , n.v. but examined for us by Professor Guido Moggi. Both Thand $q$ are illustrated. The fruit figured is stated to be immature; it has the striations characteristic of the species treated traditionally and by us as $C$. elongatus, although immature fruit of $C$. ater can also be striate. Labillardière's description of the leaf sheaths and rudimentary laminae also appear to apply to this species rather than to $C$. ater. Professor Moggi reports that the syntypes match, in all respects, specimens cited below under $C$. elongatus.

\section{Synonyms}

Hypolaena elongata (Labill.) Masters 1878, in DC. Monogr. Phan. 1: 379.

Hypolaena longissima Benth. 1878, Fl. Aust. VII: 238.

\section{Syntypes}

Foot of Mt La Perouse [as Lapeyrouse], C. Stuart, Q Herb. F. Mueller 1876 [presumably date of receipt at $\stackrel{+}{\mathrm{K}}$ ] (K). The o specimen (in $\mathrm{K}$ ) is here selected as Lectotype. Dr ${ }^{T}$. Macfarlane has confirmed, in the light

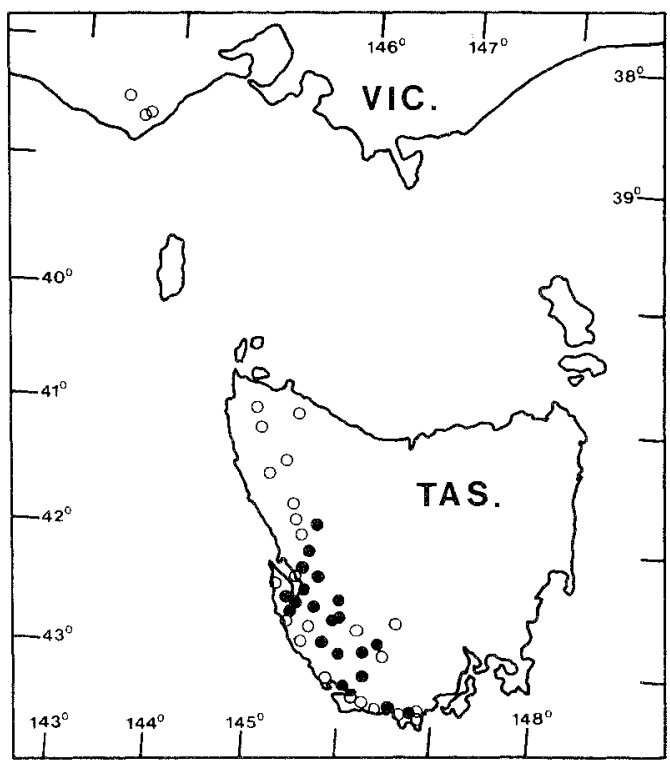

FIG, 2- The distribution of C. ater (solid circles) and C. elongatus (open circles) in Tasmania and southern Victoria. 
of the present knowledge that two species occur in Tasmania, our earlier identification as $C$. elongatus. Residual Syntypes or Isosyntypes: Base of Mt La Perouse, Stuart $\sigma^{\pi}$ (MEL 14965), 1.iii.[18]57 (MEL 14967). These sheets in MEL are not annotated by Bentham but it appears that Bentham may have examined at least one of them as part of the exchange of material between Mueller and Bentham and extracted from them the material and a small $\varnothing$ piece that now form the $\mathrm{K}$ sheet, which is labelled in Bentham's hand.

\section{Comments}

Bentham cited "Calorophus elongatus Labill. PI. Nov. Holl. ii.78 partly" in the protologues of both Hypolaena longissima and $H$. lateriflora Benth. (= Empodisma minus), citing also "t.288" only for the latter species and stating that Labillardière "appears from his description to have confounded [the two] species under one name". Bentham's comments make clear that he had not ex amined Labillardière's specimens. Although Bentham considered that Labillardière had mixed material under $C$. elongatus, we see no evidence in the protologue for such mixture.

\section{Description}

Dioecious. Forming dense tangled masses arising from a tufted base. Culms numerous, erect, much branched, often stout and up to $2.5 \mathrm{~mm}$ diameter towards the base, often rooting at the lower nodes; slender, c. $0.3-1.0 \mathrm{~mm}$ diameter above, wiry and flexuose, to $4 \mathrm{~m}$ high although usually to c. $1 \mathrm{~m}$ high, terete to slightly compressed or sometimes furrowed, substriate to subrugose or sometimes smooth, pale green, glabrous. Sheaths and floral bracts persistent, imbricate; basal sheaths often glossy red-brown; cauline sheaths initially green and closely appressed to the culm, becoming lax and brown or grey with age, smooth or striate or sometimes slightly rough with minute black protuberances, $5-25(-35) \mathrm{mm}$ long, apex obtuse to truncate with a linear, reflexed, caducous lamina up to $10 \cdot \mathrm{mm}$ long. Male spikelets single or in pairs in the axils, and when two in each axil then one shortly pedicellate, the other \pm sessile; the spikelets $3.0-4.5 \mathrm{~mm}$ long, cylindrical or narrowly ovoid, with two glumes subtending a solitary flower, the glumes ovate-lanceolate, $1.5-2.7 \mathrm{~mm}$ long, acute and sometimes with a short awn, hyaline to pale brown, membranous. Female spikelets axillary, solitary and terminal on pedicels up to $60 \mathrm{~mm}$ long; the spikelets 4.5-9.0 mm long, with two glumes subtending a solitary flower, the glumes ovate-lanceolate, $2.7-6.8 \mathrm{~mm}$ long, apex subulate, pale brown, membranous or rigid. Male flowers: tepals 6, lanceolate, acute, firm, pale brown, smooth, glabrous; 3 outer tepals $1.6-3.5 \mathrm{~mm}$ long, \pm flat; 3 inner tepals (1.6-)2.7-4.5 mm long, concave; filaments 1.5-3.5 mm long; anthers 1.3-2.4 mm long; pistillode present, up to $1 \mathrm{~mm}$ long, 3-branched. Female flowers: tepals 6 , similar to males but outer tepals 3.3-5.3 mm long, inner tepals $3.5-5.5 \mathrm{~mm}$ long; staminodes 3, 1.5-2.0 mm long; ovary 1-locular; style 2- or 3-branched, wholly stigmatic, centrally attached to the ovary. Nut ellipsoid, 2.3-3.4 mm long, brown to black with pale longitudinal ridges. Seed ellipsoid, brown. c. $2 \mathrm{~mm}$ long. Chromosome number: $2 n=22$ (Briggs in Johnson \& Cutler 1974), (vouchers: D. Martin NSW 91555 đ, Queenstown-Zeehan Road, ii.1966 (NSW); D. Martin NSW 91121 Q, Zeehan, ii.1966 (NSW, HO)).

\section{Distribution}

Western Otways of Victoria and western and southwestern Tasmania; growing among and over shrubs, along creeks, in heathy swamps and in moist forest, on peaty or sandy soils of low fertility; from low altitudes to $500 \mathrm{~m}$, but mostly below $100 \mathrm{~m}$ (fig. 2).

\section{Selected Specimens}

Victoria: Otway Ranges - S. Harris 6, on the Holy Water Track, c. $8.5 \mathrm{~km}$ southeast of Lavers Hill, 24.ii. 1984 (MEL, AD, BRI, HO, NSW); S. Harris 1 ㅇ, Otways, c. $4.5 \mathrm{~km}$ WSW of Carlisle River township, 4.vii.1983 (MEL, HO, NSW).

Tasmania: West Coast - D. Martin NSW 91554 O', NSW 89708 \&, Long Plains, Corinna road, 10.i.1966 (NSW); W. Jackson 201J, Corinna, i.1954 (HO, NSW); M. Phillips CBG 037021, $9.5 \mathrm{~km}$ from Queenstown towards Strahan, 21.xi.1965 (CBG, NSW). South West - B. Briggs 7062, Scotts Peak road, west of Mt Eliza at Old Huon River crossing, 11.xi.1980 (NSW, CANB, HO, MO, NBG); B. Briggs 8251 की Little Florentine River, $1.3 \mathrm{~km}$ southwest of The Needles, 17.x.1988 (NSW, B, BOL, CANB, HO, K, MO, NBG, PERTH); D. Morris 8022 , McPartlan Pass, Strathgordon Road, 11.i. 1980 (HO); J. Jarman, upper tributaries of the Giblin River, east of Lawson Range, i.1979 (HO); A. Brown 379 ㅇ, base of Mt Counsel, 23.iii.1984 (HO); M. Brown 16 , plain at junction of South Cape Road and South Cape Spur 2 Road, 10.xi.1981 (HO); C. Davis NSW 91557 đ̋, 91556 \&, Bramble Cove, Port Davey, 9.ii.1937 (NSW).

\section{ACKNOWLEDGEMENTS}

It is a pleasure to acknowledge the assistance of Dr Winifred Curtis and Dr Jean Jarman in making available material of these taxa and expert comment on them, and to Dr Terry Macfarlane of the Westem Australian Herbarium and Professor Guido Moggi of Florence who kindly examined and reported on specimens at 
$\mathrm{K}$ and $\mathrm{F}$. We also benefited from the opportunity to examine specimens in $\mathrm{HO}$ and MEL. Our sincere thanks go to Siegfried Krauss, who contributed greatly to the preparation of this paper, and to Dennis Morris and Alex Buchanan of the Tasmanian Herbarium and AnnaLouise Quirico (NSW) for assistance in various aspects. The drawings were prepared by David Mackay and the map by Siegfried Krauss. Assistance from the Trust of the Royal Botanic Gardens, Sydney, and an Australian Research Grant are gratefully acknowledged.

\section{REFERENCES}

JoHnson, L.A.S. \& BRIGGS, B.G., 1983: Restionaceae. In Morley, B. \& Toelken, H. (Eds): FLOWERING PLANTS IN AUSTRALIA. Rigby, Adelaide: 371-373.
JOHNSON, L.A.S. \& BRIGGS, B.G., 1985: A new species and genus of Restionaceae from Tasmania. Telopea 2 : 737-740.

JoHnson, L.A.S. \& CuTLER, D.F., 1974: Empodisma: a new genus of Australasian Restionaceae. Kew Bull. 28: $381-385$.

Harris, S.G., 1984: Calorophus elongatus Labill. (Restionaceae) - a new record for the Australian mainland. Vict. Nat. 101: 163-165.

MorRIs, D.I., 1991: Restio hookeri, a new name for a familiar Tasmanian species. Pup. Proc. R. Soc. Tasm. 124(2): 33-34.

ORCHARd, A.E., 1988: A natural regions map for Tasmania. Pap. Proc. R. Soc. Tasm. 122: 47-51.

(accepted 10 August 1990)

L.A.S. Johnson and B.G. Briggs

Royal Botanic Gardens, Sydney, NSW, Australia 2000 